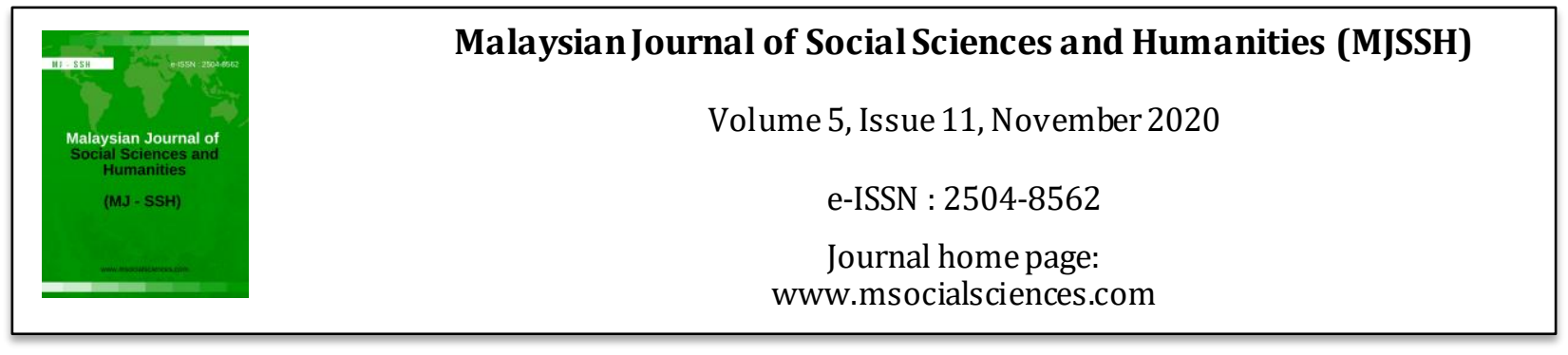

\title{
Factors Affecting Job Satisfaction among Academic Employees in Polytechnic
}

\author{
Muhamad Saufiyudin Omar'1, Siti Fatimah Abdul Aziz' ${ }^{2}$, Nurasyikin Mohd Salleh ${ }^{1}$ \\ ${ }^{1}$ Department of Tourism and Hospitality, Politeknik Tuanku Syed Sirajuddin, Pauh Putra, 02600 Arau, Perlis, \\ Malaysia. \\ ${ }^{2}$ Department of Tourism and Hospitality, Politeknik Sultan Idris Shah, Sungai Lang, 45100 Sungai Air Tawar, \\ Selangor Darul Ehsan, Malaysia. \\ Correspondence: Muhamad Saufiyudin Omar (saufiyudin@yahoo.com)
}

\begin{abstract}
Satisfied employees are crucial in developing a successful organization. The purpose of this study is to identify the factors that affect job satisfaction among polytechnic academic employees in Malaysia. A cross-sectional study was employed and stratified random sampling was used to collect the data. A total of 130 respondents answered the questionnaires. The results revealed that job security, salary and working conditions had significant and positive influence on job satisfaction among polytechnic academic employees. Hence, strengthening the factors of job security, salary and working conditions among the polytechnic academic employees is critically important to ensure the employees are satisfied which will then lead towards a successful polytechnic.
\end{abstract}

Keywords: job security, job satisfaction, salary, working conditions, polytechnic Malaysia.

\section{Introduction}

Job satisfaction is important for an employee and organizational performance. Job satisfaction refers to the employee's subjective feelings towards his/her satisfaction at workplace on physical and psychological level (Hsiao \& Lin, 2018). Usually, satisfied employees tend to be less absent, less likely to leave, are more productive, and are more likely to display organizational commitment and be satisfied with their lives (Singh \& Jain, 2013). However, if the employees are not satisfied, their productivity will drop and consequently lead them to think about quitting (Sohag, Menon, Mahmood-ur-Rahman, \& Rao, 2012).

In this light, Polytechnic academic employees may gain higher job satisfaction if they are happier and enjoy their job. Similar to the higher learning institutions in Malaysia, polytechnic academics are facing challenges that are bound with multiple and complicated works in an increasingly demanding environment (Sikul, Harun, Mohta, \& Eranza, 2015). In addition, the academics also need to multitask, switching between the academic and non-academic tasks to ensure the organization can operate smoothly. As mentioned by Kalleberg (1977), an employee may be satisfied with one or some of the job responsibilities he or she has but dissatisfied with the other tasks in hand. Therefore, a study on the factors that influence Polytechnic academic employees' job satisfaction is critical to improve the organization's performance. 
Polytechnics in Malaysia are one of the hubs for the nation's human capital development (Jaafar, 2013). Its role has been expanded and its establishment has been rebranded in making sure the nation's missions are accomplished by providing the human capital source to the industrial sectors to generate economic growth (Jabatan Pengajian Politeknik, 2009). In addition, Polytechnics in Malaysia focus on the skill-based subjects related to technical and vocational education and training (TVET) that have been improvised and improved in order to be in line with the nation's plan in achieving Vision 2020 (Abdullah \& Majid, 2013). Hence, a study on human capital especially the teaching employees is critically important due to the high demand and challenges faced by the Polytechnic academics in teaching the targeted skills to the future students.

Most researches have studied the association between job security, salary and working conditions with job satisfaction in the global stages (Bakotic \& Babic, 2013; du Plessis et al., 2016; Senol, 2011). However, very limited researches have focused on job security, salary and working conditions with job satisfaction among Malaysian Polytechnic academics (Abdullah \& Majid, 2013; Kumar \& Muniandy, 2012). Thus, the objective of this study is to investigate the influence of job security, salary and working conditions on job satisfaction among Polytechnic academics in the Malaysian context. This study will be useful in increasing the job satisfaction level among polytechnic academic employees besides enriching the body of knowledge in that particular area. Besides that, it can help the Head of Department $(\mathrm{HoD})$ and management team to improve the employees' job satisfaction.

\section{Literature Review}

\section{Job security}

Job security is an intangible, powerful, and emotional factor that is distinctly individualized (Dienhart \& Gregoire, 1993). Job security is crucial for an employee in terms of keeping his or her job (Senol, 2011). Employees who have a sense of job security think they are given a fair chance to utilize their skills to the degree that their importance to the organization will guarantee acceptance and personal growth (Dienhart \& Gregoire, 1993). In addition, employees that feel secure in their jobs are less resistant to change, while the insecure employees are less committed to their work and organization (Dienhart \& Gregoire, 1993). Job security plays an important role in social and working life (Senol, 2011). It is because job security prevents individuals from worrying about their future, contributes to maintaining labour peace, increasing organization's productivity and protecting social balance and values. Furthermore, job security can also have a direct economic impact on individual and organization (Dienhart \& Gregoire, 1993). For this very reason, in order not to cause employee's prestige loss in society, employees should not be dismissed from the organizations without reasonable grounds, because job security has political and social dimensions (Senol, 2011).

\section{Salary}

Salary plays a vital role to make employees satisfied and influence the level of job satisfaction among the employees (du Plessis, Douangphichit, \& Dodd, 2016). Therefore, salary has significant relationship with job satisfaction (Fareed \& Jan, 2016). The effect of salary on job satisfaction is very important because employees always compare their hard work with the salary they earn (du Plessis et al., 2016). In addition, it cannot be denied that employers always use salaries to attract, retain and motivate employees (Teck-Hong \& Waheed, 2011). According to Robbins (2001), salary can be considered as a scorecard by the employees because they use it to evaluate the extent to which the organization values them. However, there are some views on the role of salary. Kochan (2002) argues that salary can only produce temporary compliance for the employee, but it cannot change the employee's attitude and behaviour in the long run. In addition, Kovach (1987) stated that younger employees with low incomes were more concerned about money whereas older employees with higher incomes in management positions were mostly looking for better job security and recognition. 
According to Lawler (1973), employee salary satisfaction usually affects their job satisfaction. Tang et al. (2004) found that salary satisfaction is part of job satisfaction, which can increase employee productivity. Tang et al. (2004), also stated that the love of money reflects the employees' wants and values, and employees who highly values his/her salary, will be satisfied with the salary and then be satisfied with the job when he/she receives the desired increment. Some employees feel that they never had enough money and would want to have higher salary because they consider salary as the most important purpose in their lives (Teck-Hong \& Waheed, 2011). Usually, this type of employees would want to achieve more and they will work harder if they are satisfied with the salary received.

\section{Working conditions}

Working conditions play a vital role in the employees' perspective. According to Fareed and Jan (2016), employees feel dissatisfied if they work in a poor working condition. These working conditions include ventilation, working hours, temperature and many more. In addition, most employees prefer working conditions that are not dangerous and unpleasant (Robbins, 1998). Many researchers have found that working condition significantly and positively influence job satisfaction (Bakotic \& Babic, 2013; Fareed \& Jan, 2016; Chevalier, Fouquereau, Bénichoux \& Colombat, 2019). Therefore, it is necessary to eliminate uncomfortable working conditions. At the same time, the safety of the working conditions is critically important to avoid danger to employee's life or health and to avoid accidents, injuries, and occupational diseases (Bakotic \& Babic, 2013).

\section{Job satisfaction}

Locke (1976) defined job satisfaction as a pleasurable or positive emotional state that is related to the work that individual performs. Whereas, Leap and Crino (1993) defined job satisfaction as the attitude of a worker toward his job, rewards he gets, and the social, organizational and physical characteristics of the environment in which he performs his working activities. Job satisfaction is a complex concept that is influenced by various factors such as nature of work, salary, stress, working conditions, colleagues, superiors, working hours and many more (Bakotic \& Babic, 2013). Having high job satisfaction influences an employee's work behaviour, thus increase the performance of the organization. Job satisfaction is an interesting problem that involves the points of view of the employee and employer (Bakotic \& Babic, 2013). From the employee's point of view, they want their manager to be fair, treat them with respect, and these will satisfy their work. From the manager's point of view, he/she wants satisfied employee to be committed to work, portray positive attitudes and be emotionally involved to their job (Bakotic \& Babic, 2013). These are the key areas that can determine organizational success, and avoid negative impacts on the organizational performance.

\section{Conceptualframework}

Based on Figure 1, the independent variables are job security, salary and working conditions, while, the dependent variable is job satisfaction. Based on the framework, this study proposed the following three hypotheses:

Hypothesis 1: Job security positively influence job satisfaction among polytechnic academic employees. Hypothesis 2: Salary positively influence job satisfaction among polytechnic academic employees. Hypothesis 3: Working conditions positively influence job satisfaction among polytechnic academic employees. 


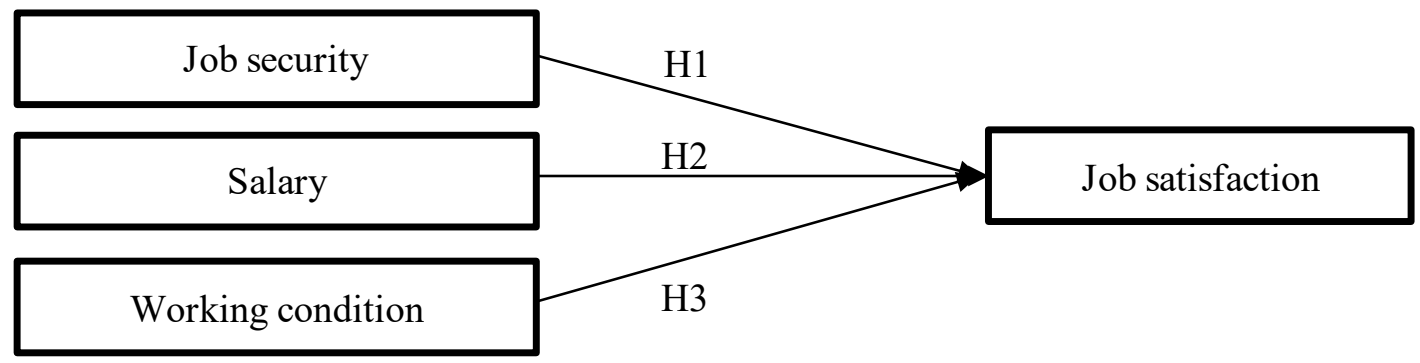

Figure 1: Conceptual framework of the study

\section{Methodology}

This study utilized a quantitative approach with a survey method in order to collect data. The population of this research comprised individuals who work at the Department of Tourism and Hospitality in four polytechnics in Malaysia as lecturers. They are civil servants and most of them have worked for more than six years. Based on Krejcie and Morgan's (1970) table of sample size, when the population size is 169 , the required sample size is 118. Data were collected from the questionnaires completed by employees working in four polytechnics in Malaysia.

In terms of the questionnaire, the study adapted from previous researchers. Respective questions related to salary were adapted from Smerek and Peterson (2007), working conditions and job security from Teck-Hong and Waheed (2011), while job satisfaction from Brayfield and Rothe (1951). In order to make it more suitable to the study, some modifications were done to the questionnaire. The questionnaire was divided into six parts; Part A: Demographic profile (7 items), Part B: Job security (5 items), Part C: Salary (5 items), Part D: Working conditions (5 items), and Part E: Job satisfaction (18 items). A fivepoint Likert scale was employed ranging from ' 1 -Strongly disagree' to '5-Strongly agree' to measure all variables and SPSS was utilized to analyse the data.

In terms of data collection, the questionnaire was attached with a letter from the researchers to inform the respondents about the research objective and that all data gathered will be treated as confidential. In addition, the respondents were also informed that the questionnaire will take approximately about 15 minutes to complete. The questionnaire is personally self-administered and the involvement by the respondent is on a voluntary basis. Stratified random sampling was used to collect the data.

\section{Result}

\section{Respondents demographic}

Out of 169 samples, only 130 responded to the questionnaire and gave a response rate of $77 \%$. The results revealed that more female employees $(74.6 \%)$ answered the questionnaire compared to the male employees (25.4\%). Most of the respondents were aged between 31-40 years old (69.2\%), followed by those between $41-50$ years old (25.4\%) and the lowest were between 51-60 years old (0.8\%). Majority of the respondents were Malays (99.2\%) and the remaining $0.8 \%$. were of other races. In terms of the job tenure, most of the respondents have worked for between $11-15$ years $(44.6 \%)$, followed by $6-10$ years $(32.3 \%)$ and 15 years and above $(13.8 \%)$. The largest group of respondents for this study $(60 \%)$ were employees from Politeknik Tuanku Syed Sirajuddin (PTSS) (39 employees) and Politeknik Sultan Idris Shah (PSIS) (39 employees), followed by Politeknik Merlimau Melaka (PMM) with 36 employees $(27.7 \%)$ and lastly Politeknik METrO Kuantan (PMKu) with 16 employees (12.3\%). Table 1 provides the demographic profile of the respondents. 
Table 1: Demographic profile of respondents

\begin{tabular}{llll}
\hline Demographic variables & Category & Frequency & Percentage (\%) \\
\hline Gender & Male & 33 & 25.4 \\
& Female & 97 & 74.6 \\
Age & $21-30$ years old & 6 & 4.6 \\
& $31-40$ years old & 90 & 69.2 \\
& $41-50$ years old & 33 & 25.4 \\
Race & $51-60$ years old & 1 & 0.8 \\
\multirow{2}{*}{ Job Tenure } & Malay & 129 & 99.2 \\
& Others & 1 & 0.8 \\
& 1-5 years & 12 & 9.2 \\
Polytechnic & 6-10 years & 42 & 32.3 \\
& 11-15 years & 58 & 44.6 \\
& 15 years and above & 18 & 13.8 \\
& PTSS & 39 & 30.0 \\
& PSIS & 39 & 30.0 \\
& PMKu & 16 & 12.3 \\
\hline
\end{tabular}

\section{Reliability}

Table 2 shows the result of Cronbach's Alpha of job security, salary and working conditions to measure the reliability of the instrument. The results showed that job security was 0.901 , salary was 0.814 , working conditions was 0.851 , and job satisfaction was 0.901 . It can be concluded that all variables were reliable.

Table 2: Cronbach's Alpha

\begin{tabular}{lc}
\hline Variables & Value of Cronbach's Alpha \\
\hline Job security & 0.901 \\
Salary & 0.814 \\
Working conditions & 0.851 \\
Job satisfaction & 0.901 \\
\hline
\end{tabular}

\section{Correlation analysis}

The Pearson correlation showed the correlation of job security, salary and working conditions on job satisfaction. The result indicated that there were positive relationships between job security and job satisfaction $(r=0.411)$, salary and job satisfaction $(r=0.452)$, and working conditions and job satisfaction $(r=0.365)$. Based on the findings, the strongest positive correlation was between job satisfaction and salary, followed by job satisfaction and job security and eventually the weakest correlation was between job satisfaction and working conditions. Table 3 showed the correlation analysis of the study.

Table 3: Correlation analysis of study

\begin{tabular}{lllllll}
\hline Variables & Mean & Std dev. & $\begin{array}{l}\text { Job } \\
\text { security }\end{array}$ & Salary & $\begin{array}{l}\text { Working } \\
\text { conditions }\end{array}$ & $\begin{array}{l}\text { Job } \\
\text { satisfaction }\end{array}$ \\
\hline Job security & 4.191 & .513 & & & & \\
Salary & 3.920 & .482 & $.390^{* *}$ & & & \\
Working & 3.927 & .653 & $.221^{* *}$ & $.405^{* *}$ & & \\
conditions & & & & & \\
Job satisfaction & 3.842 & .411 & $.411^{* *}$ & $.452^{* *}$ & $.365^{* *}$ & \\
\hline
\end{tabular}

**Correlation is significant at the 0.01 level (1-tailed). 


\section{Multiple regression analysis}

The multiple regression analysis was used to analyse the influence of job security, salary and working conditions and job satisfaction. The results in Table 4 indicate that $\mathrm{R}^{2}=0.327$, which means that job security, salary and working conditions, explained $32.7 \%$ of the variance in the job satisfaction with $F$ $=26.479, p=0.000$. The remaining of $67.3 \%$ were explained by the other factors. In this case, job security, salary and working conditions contribute significantly and positively towards the prediction of job satisfaction with the beta values of $0.225 ; 0.226$ and 0.169 , respectively. Hence, hypotheses 1,2 and 3 were supported and showed that job security, salary and working conditions significantly and positively influence job satisfaction in the context of Polytechnic employees.

Table 4: Multiple regression analysis

\begin{tabular}{llllll}
\hline Model & $\mathrm{B}$ & SE B & $\beta$ & $\mathrm{t}$ & Sig. \\
\hline (Constant) & 1.198 & .352 & & 3.401 & .001 \\
Job security & .181 & .066 & .225 & 2.761 & .007 \\
Salary & .193 & .075 & .226 & 2.582 & .011 \\
Working conditions & .107 & .051 & .169 & 2.075 & .040 \\
\hline
\end{tabular}

Note: $\mathrm{R}^{2}=.327, p<0.00$.

\section{Discussion}

The main objective of this study was to examine the influence of job security, salary and working conditions on job satisfaction of the polytechnic academic employees. Based on the empirical findings gathered, the result indicated that job security, salary and working conditions had significant and positive influence on job satisfaction. Most of the employees agreed that the organization did a good job in providing steady employment for them. In other words, the employees feel secure with their current job. Therefore, the employees feel safe with the job. This is consistent with Senol (2011) who stated that job security is crucial for the employee in keeping his or her job.

In terms of salary, the employees feel appropriate with the increment provided. They also agreed that the salary they received is much more competitive compared to other organizations. Hence, the respondents agreed that the salary they received is the significant factor that make them stay in the organization. As mentioned by du Plessis et al. (2016), employees will compare the salary received to their efforts to determine their job satisfaction.

The working condition also plays a vital role in determining the polytechnic's academic employee's job satisfaction. The employees feel that their physical surrounding is pleasant, and they are satisfied with the lighting, heating, and ventilation at their workplace. In addition, the location of their workplace is also a significant factor that satisfied them. Hence, the comfort level of the working condition critically influences the polytechnic's academic employee's job satisfaction.

\section{Conclusion}

In summary, this study found that job security, salary and working conditions significantly and positively influence job satisfaction among the Polytechnic academic employees, especially the employees in the Department of Tourism and Hospitality. Moreover, the findings also suggested that the employees of the Department of Tourism and Hospitality agreed that salary had the highest influence to their job satisfaction followed by job security and lastly working condition.

Few limitations were identified in this study. Firstly, this study focuses only on the employees at the Department of Tourism and Hospitality, perhaps in the future, similar research can include other 
departments such as the Electrical Engineering Department, Mechanical Engineering Department, Department of Information Technology and Communication and Commerce Department. Secondly, this study focused only on the academic employees, thus future research can include the management and non-management employees in the Polytechnic as well.

\section{References}

Abdullah, S., \& Majid, F.A. (2013). English language teaching challenges in Malaysia: Polytechnic lecturers' experience. World Applied Sciences Journal, 28(4), 540-547.

Bakotic, D., \& Babic, T. (2013). Relationship between working conditions and job satisfaction: The case of Croatian shipbuilding company. International journal of business and social science, 4(2), 206-213.

Brayfield, A. H., \& Rothe, H. F. (1951). An index of job satisfaction. Journal of Applied Psychology, 35(5), 307-311.

Chevalier, S., Fouquereau, E., Bénichoux, F., \& Colombat, P. (2019). Beyond working conditions, psychosocial predictors of job satisfaction, and work engagement among French dentists and dental assistants. Journal of Applied Biobehavioral Research, 24(1), 1-10.

Ćulibrk, J., Delić, M., Mitrović, S., \& Ćulibrk, D. (2018). Job satisfaction, organizational commitment and job involvement: The mediating role of job involvement. Frontiers in Psychology, 9, 132.

Dienhart, J. R., \& Gregoire, M. B. (1993). Job satisfaction, job involvement, job security, and customer focus of quick-service restaurant employees. Hospitality Research Journal, 16(2), 29-43.

Du Plessis, A. J., Douangphichit, N., \& Dodd, P. (2016). HRM in relation to employee motivation and job performance in the hospitality industry. Journal of International Business Research and Marketing, 1(4), 12-21.

Fareed, K., \& Jan, F. A. (2016). Cross-Cultural Validation Test of Herzberg's Two Factor Theory: An Analysis of Bank Officers Working in Khyber Pakhtunkhwa. Journal of Managerial Sciences., $10(2), 285-300$.

Hsiao, J. M., \& Lin, D. S. (2018). The Impacts of Working Conditions and Employee Competences of Fresh Graduates on Job Expertise, Salary and Job Satisfaction. Journal of Reviews on Global Economics, 7, 246-259.

Jaafar, A. K. (2013). Transformasi politeknik fasa dua. Opening Speech at Kolokium Kecermelangan Akademik Pegawai Pendidikan Pengajian Tinggi, Kuala Lumpur.

Jabatan Pengajian Politeknik (2009). Hala tuju transformasi politeknik: Ke arah kelestarian penghasilan modal insan negara. Kementeria Pengajian Tinggi. Putrajaya.

Kalleberg, A. L. (1977). Work values and job rewards: A theory of job satisfaction. American Sociological Review, 42(1), 124-143.

Kochan, T. A. (2002). Addressing the crisis in confidence in corporations: root causes, victims, and strategies for reform. Academy of Management Executives, 16(3), 139-141.

Kovach, K. A. (1987). What motivates employees? Workers and supervisors give different answers. Business Horizons, 58-65.

Kumar, J. A., Muniandy, B., \& Yahaya, W. A. J. W. (2018). Exploring How Emotional Intelligence and Academic Achievement In? uences E-Learning Achievement: A Case Study in Malaysian Polytechnics. Advanced Science Letters, 24(1), 226-229.

Lawler, E. E. (1973). Employee reactions to job characteristics. Journal of Applied Psychology, 55, 259286.

Leap, T. L, \& Crino, M.D. (1993). Personnel/Human Resource Management. Macmillian Publishing Company.

Locke, E. A. (1976). The nature and causes of job satisfaction, In Dunnette, M. D., Editor. Handbook of Industrial/Organizational Psychology, McNally, Chicago, 1297-1346.

Mani, B. G. (2002). Performance appraisal systems, productivity, and motivation: a case study. Public Personnel Management, 31, 141-59.

Robbins, S. P. (2001). Organizational behavior (9th ed.). New Jersey: Prentice Hall.

Şengür, D., \& Turhan, M. (2018). Prediction of the action identification levels of teachers based on organizational commitment and job satisfaction by using KNearest neighbors method. Turkish Journal of Science \& Technology, 13(2). 
Senol, F. (2011). The effect of job security on the perception of external motivational tools: A study in hotel businesses. Journal of Economic and Social Studies, 1(2), 33-67.

Sikul, R., Harun, A., Mohta, T. M., \& Eranza, D. R. D. (2015). Factors influencing job performance: A case study amongst teaching staff in Kota Kinabalu Polytechnic. Malaysian Journal of Business and Economics, 2(2), 41-58.

Singh, J. K., \& Jain, M. (2013). A study of employees 'job satisfaction and its impact on their performance. Journal of Indian Research, 1(4), 105- 111.

Smerek, R. E., \& Peterson, M. (2007). Examining Herzberg's Theory: Improving job satisfaction among non-academic employees at a university. Research in Higher Education, 48(2), 229-250.

Sohag, A. A., Memon, S., Mahmood-ur-Rahman, \& Rao, M. H. (2012). A comparative study on factors causing job dissatisfaction among serving doctors at teaching hospitals of Hyderabad, Pakistan. Pakistan Journal of Medical Sciences, 28(4), 710-715.

Tang, T. L. P., Luna-Arocas, R., Sutarso, T., \& Tang, D. S. H. (2004). Does the love of money moderate and mediate the income-pay satisfaction relationship? Journal of Managerial Psychology, 2, $111-$ 135.

Teck-Hong, T., \& Waheed, A. (2011). Herzberg's motivation-hygiene theory and job satisfaction in the Malaysian retail sector: The mediating effect of love of money. Asian Academy of Management Journal, 16(1), 73-94. 